\title{
Is the perception of leaving the job of the lecturers influenced by quality work of life?
}

\author{
Julianti Kasih* \\ Faculty of Information Technology Maranatha Christian University \\ J1. Surya Sumantri No. 65, Sukawarna, Kec. Sukajadi, Kota Bandung, 40164, Indonesia \\ julianti.kasih@it.maranatha.edu \\ Teddy Marcus Zakaria \\ Faculty of Information Technology Maranatha Christian University \\ Jl. Surya Sumantri No. 65, Sukawarna, Kec. Sukajadi, Kota Bandung, 40164, Indonesia \\ teddy.marcus@it.maranatha.edu \\ *Penulis Korespondensi
}

Submitted: Feb 25, 2021; Reviewed: Mar 4, 2021; Accepted: Apr 12, 2021

\begin{abstract}
We know the lecturer workforce turnover for a university has considerable trouble. The lecturers' rapid turnover will influence the teaching process's stability. To shorten the lecturer workforce's turnover, the university desires to have an effort to enhance the quality of the lecturers' work-life. This research decides to create life's variables, which is a variables aspect for Maranatha Christian University lecturers to resign from their jobs. Using a survey method to get the data, it distributed questionnaires to 150 lecturers from Maranatha Christian University. The data collected were treated using Amos 22 software. The supervision style and job satisfaction variables' correlation results showed 5.33 and the relationship between salary allowances and supervision style showed a precise result. The conclusion obtained for Maranatha Christian University's lecturers, the quality of work-life, appears not instantly to touch lecturers' desire to move their jobs. However, the supervision and calculation of allowance salaries directly affect job satisfaction, although this relationship realistic presently affects lecturers to drop their jobs. The purpose of this research is to provide information for Maranatha Christian University. This research aims to scale down the lecturers' workforce turnover by increasing the quality work of life variables.
\end{abstract}

Keywords: job satisfaction; leave work; lecturer; turnover of labor; work of life

Abstrak: Masalah perputaran tenaga kerja dosen bagi sebuah perguruan tinggi dirasakan sebagai
suatu masalah yang besar. Perputaran tenaga kerja yang cepat dari para dosen akan memberikan
dampak bagi kestabilan proses pengajaran yang diberikan. Dalam rangka untuk menekan perputaran
tenaga kerja dosen, maka universitas perlu memiliki upaya agar kualitas kehidupan kerja para dosen
ditingkatkan. Berdasarkan hal tersebut, maka penelitian ini mencoba memodelkan variabel-variabel
dari kualitas kehidupan kerja yang menjadifaktor-faktor dosen Universitas Kristen Maranatha mundur
dari pekerjaannya. Mengunakan metode penelitian survei, maka untuk mendapatkan data penelitian
dilakukan penyebaran kuesioner terhadap 150 orang dosen dari Universitas Kristen Maranatha. Data
yang diperoleh diolah dengan menggunakan software Amos 22. Hasil korelasi variabel gaya
pengawasan dengan kepuasan kerja menunjukkan angka sebesar 5,33. Demikian juga untuk hubungan
antara gaji tunjangan terhadap gaya pengawasan menunjukkan hasil yang positif. Kesimpulan yang
diperoleh bagi dosen Universitas Kristen Maranatha, kualitas kehidupan kerja tidak berpengaruh
langsung terhadap keinginan dosen untuk meninggalkan pekerjaannya. Namun, gaya pengawasan dan 
penghitungan gaji tunjangan berpengaruh positif terhadap kepuasan kerja, meskipun hubungan ini tidak berpengaruh secara langsung bagi dosen untuk keluar dari pekerjaannya. Tujuan penelitian ini agar dapat memberi masukan bagi Universitas Kristen Maranatha, untuk menurunkan perputaran tenaga kerja para dosennya dengan cara meningkatkan nilai dari ketiga variabel kualitas kehidupan kerja tersebut.

Kata kunci: dosen; kepuasan kerja; kualitas kehidupan kerja; meninggalkan pekerjaan; perputaran tenaga kerja

\section{INTRODUCTION}

Improving the lecturer's quality of work life is an issue that universities must concern (Mirkamali \& Thani, 2011) that has positive conjunction on increasing job satisfaction and will further increase the desire to leave the lecturers' work (Alzalabani, 2017). Research conducted by Farid among the lecturers in a Malaysian Public Research University found that quality of working life (QWL) is a factor that determines organizational commitment (Farid et al., 2015). While the research conducted by Alzalabani to measure quality work of life used variables including moral environment, job characteristics, participation in decision-making processes, job satisfaction, wages and numeration, teamwork, and supervision style (Alzalabani, 2017).

Based on the above research and the purpose of this research to reduce the turnover of the lecturer, the writer tries to measure perception of leaving the job by using five quality work of life variables from Alzabani (2017), such as moral environment, job characteristics, salary and allowances, supervision style, and job satisfaction. Get the data from primary sources and the variables are manifest as questionnaires, we will distribute those to respondents, namely lecturers from Maranatha Christian University in Bandung. The next step was to validate and process the SPSS-IBM AMOS program's data. The results will be analyzed, measured to produce models and formulations expected to reference material to predict lecturers' desire to leave their work.

Suppose the research results have a positive relationship between quality work of life and the desire to leave work with lecturers. In that case, there is hope that will be an improvement in the lecturers' work world by developing the factors that influence it. We expect the institution to build lectures' work of life and welfare to have high loyalty and desire to continue working in the same place. Without that, the stability of teaching and learning process will be a challenge. Afterward, the majority will notice it and decrease the applicant of students.

Organizations need to pay attention to the quality work of life because it contributes to workers leaving employment (Almarsh, 2015). Previous studies found significant evidence that quality work of life affected the increase in employee job satisfaction (Alzalabani, 2017); moreover, this will affect the employee's decision to stay on the job or leave work (Zamanan et al., 2020). New strategies for attracting and retaining skilled workforce require organizations' better actions in evaluating the quality work of life (QWL) of their employees (Almarsh, 2015), because work-life balance is an essential issue for employees (Mesimo-Ogunsanya, 2017).

Although the effects of job satisfaction or dissatisfaction on the lecturer's choices to leave their jobs varied, this paper examined the relationship between it and Maranatha Christian University's lecturers to enhance life quality. It will test the five hypotheses for connections using the Structural Equation Model method found in the SPSS 22-Amos data processing software.

Hypothesis I: the relationship between the construct of work ethics and job satisfaction.

The relationship between work ethics and job satisfaction has not been discussed critically in the past. Although the individual involves in ethical interactions and enrichments, the behavior can change positively, resulting in positive job satisfaction (Panigrahi \& Al-Nashash, 2019). Therefore, the present study examines the relationship between work ethics and job satisfaction among lecturers to indicate the lecture's perception of leaving the job.

Hypothesis II: the relationship between constructs of job characteristics and job satisfaction.

Job characteristics determine a person's suitability with a particular field of work and enable a person to be more successful in his career. As stated in the past research, job characteristics have a positive but 
not significant relationship to employee performance (Sugianto et al., 2018). In this research, we will examine the relationship of the constructs.

Hypothesis III: the relationship between constructs of wages and numeration and job satisfaction. Listed in the journal of comparison satisfaction and wages, there is a positive relevance between wage increases and job satisfaction (Grund \& Rubin, 2017).

Hypothesis IV: the relationship between constructs of supervision style and job satisfaction. Leaders who provide support positively impact job satisfaction (Qureshi et al., 2019); support is a motivational factor that includes this paper.

Hypothesis V: the relationship between constructs of job satisfaction and perception of leaving a job. There was a significant negative relationship between job satisfaction and turnover intention among Tanzania lecturers. Those highly satisfied were less likely to intend to leave their job (Amani, 2016).

Based on the above framework, we try to describe the following model.

\section{The influence of quality work of life to perception of leaving the job}

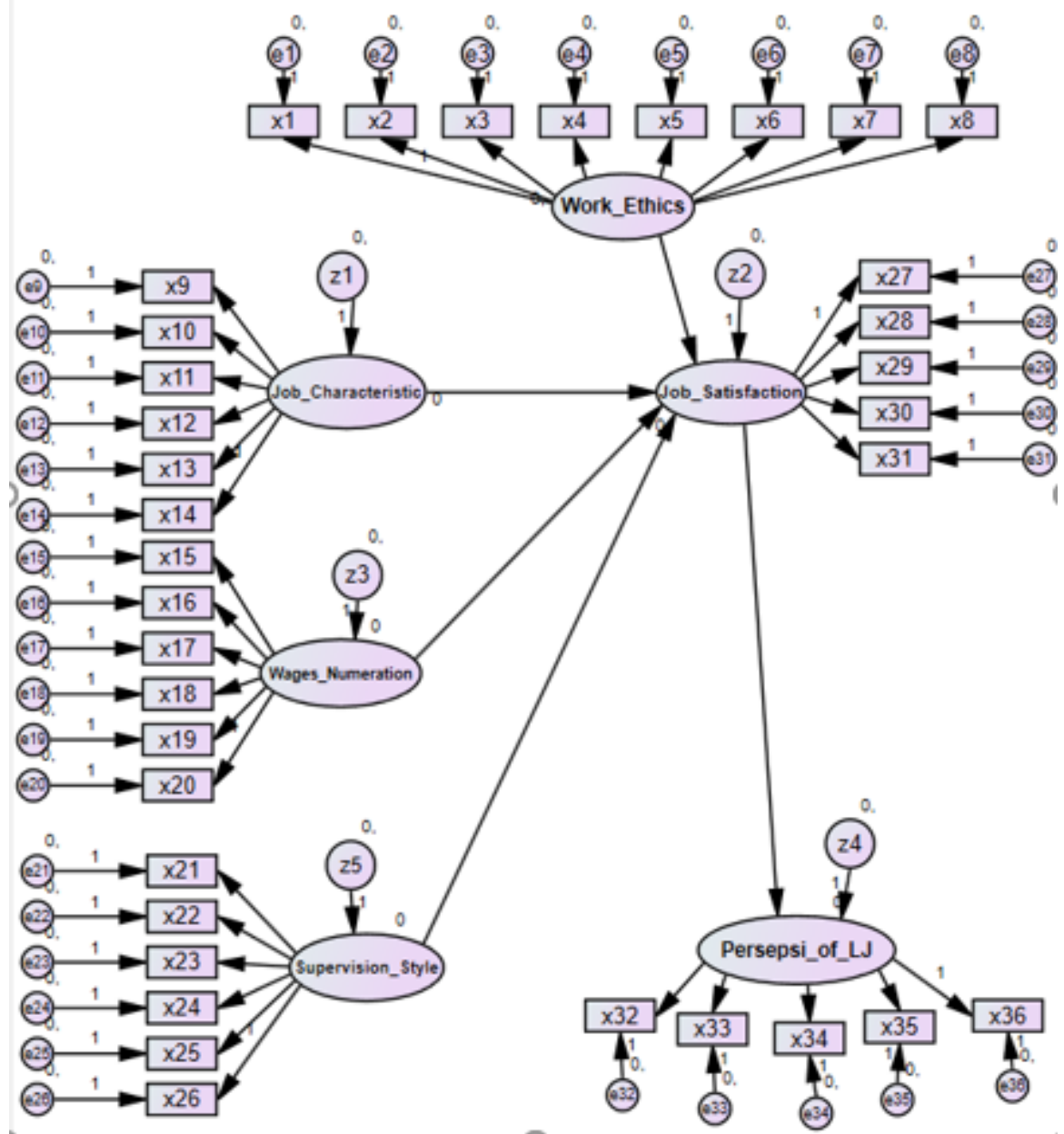

Figure 1. Model of the influence of quality work of life to the perception of leaving the job Source: AMOS 19 figure (2020)

We describe the latent variable or commonly referred to as the construct of the perception model of desiring to leave a job comprising work ethics, job characteristics, salary and benefits, style of supervision, job satisfaction, and perception of leaving the job where each construct has manifest variables as the following Table 1 . 
Table 1. Construct and manifest model perceptions of leaving the job

\begin{tabular}{|c|c|c|}
\hline Construct & Symbol & Manifest \\
\hline \multirow[t]{8}{*}{ Work ethics } & $\mathrm{X} 1$ & Care \\
\hline & $\mathrm{X} 2$ & Ethic code \\
\hline & $\mathrm{X} 3$ & Regulation \\
\hline & $\mathrm{X} 4$ & Instrumental \\
\hline & $\mathrm{X} 5$ & Hard work \\
\hline & X6 & Independence \\
\hline & $\mathrm{X} 7$ & Time \\
\hline & $\mathrm{X} 8$ & Goal \\
\hline Job & X9 & Importance \\
\hline \multirow[t]{5}{*}{ characteristic } & $\mathrm{X} 10$ & Job responsibility \\
\hline & $\mathrm{X} 11$ & Job required skills \\
\hline & $\mathrm{X} 12$ & Freedom in job \\
\hline & $\mathrm{X} 13$ & Volume of work \\
\hline & X14 & Task challenge \\
\hline Wages and & $\mathrm{X} 15$ & Happy with the income \\
\hline \multirow[t]{5}{*}{ numeration } & $\mathrm{X} 16$ & Skill and efforts \\
\hline & $\mathrm{X} 17$ & Amount of work \\
\hline & $\mathrm{X} 18$ & Fair comparing the colleagues \\
\hline & X19 & Wages system \\
\hline & $\mathrm{X} 20$ & Rewards and compensation \\
\hline Supervision & $\mathrm{X} 21$ & Encouragement \\
\hline \multirow[t]{5}{*}{ style } & $\mathrm{X} 22$ & Sharing information \\
\hline & $\mathrm{X} 23$ & Fair treatment \\
\hline & $\mathrm{X} 24$ & Motivation \\
\hline & $\mathrm{X} 25$ & Ability to plan \\
\hline & $\mathrm{X} 26$ & Capability \\
\hline Job & $\mathrm{X} 27$ & Salary \\
\hline \multirow[t]{4}{*}{ satisfaction } & $\mathrm{X} 28$ & Promotion \\
\hline & $\mathrm{X} 29$ & Co-worker \\
\hline & $\mathrm{X} 30$ & Supervisor \\
\hline & X31 & Job itself \\
\hline \multirow{5}{*}{$\begin{array}{l}\text { Perception of } \\
\text { leaving the } \\
\text { job }\end{array}$} & X32 & Better job \\
\hline & X33 & Same industry \\
\hline & X34 & Different field \\
\hline & X35 & Low in passion \\
\hline & $\mathrm{X} 36$ & Overload work \\
\hline
\end{tabular}

Source: Design authors based on Alazabani's research (2017)

The better the work ethic that employees own, it will support creating an excellent organizational climate (Tangdigling et al., 2019). Moreover, overwork ethics is one of the critical attributes that can increase employee job satisfaction and other organizational outcomes (Panigrahi \& Al-Nashash, 2019). In contrast, job satisfaction is one of the constructs of quality work of life used in this research. The work ethics' construct has eight manifestations manifested in the questionnaire (Alzalabani, 2017).

Work characteristics as meaningful work, which requires responsibility, require expertise to do freely. The workload is suitable and full of challenges (Alzalabani, 2017). Using technology in the work environment is a must; however, whether the simultaneous news and accessible information as a job characteristic make us happy and affect quality working life (Korunka \& Hoonakker, 2014).

Euro Foundation for improving living and working conditions found that wages level is an essential argument in job mobility. More than one-third of the respondents $(34,7 \%)$ give 'a higher wage' as a reason for their intention to change jobs (Vermandere, 2013). There are six manifestations of the salaries and allowances' construct, namely the level of income, salary under expertise, the study system is understood, salary is comparable to friends, the workload is similar, and there are compensation and rewards (Alzalabani, 2017). 
We expect managers to have a supervising style that is motivating, fair, planned, has a positive effort to share knowledge and information (Alzalabani, 2017). The supervision style as part of quality work of life has a significant role in skilled and trained workers leaving (Rizwan, 2014). The manifests of the construct of job satisfaction such as salary, promotion, co-workers, supervisors, and working conditions, are variables that contribute to increasing job satisfaction (Alzalabani, 2017). Low job satisfaction and joint organizational commitment included as determinants of turnover intention among information technology (Burrell, 2014).

It defines the desire to leave a job as an employee's plan to go to the current job and look for another job in the future. We can also say the desire to leave a position to be an unpredictable, inevitable matter (Zamanan et al., 2020). Five factors that manifest the desire to leave a job are getting a better job, getting a career in the same industry, bringing in a different industry, not having enthusiasm at work, and too much work (Alzalabani, 2017).

\section{METHOD}

It was using a cross-sectional study conducted at Maranatha Christian University. A total of 150 lecturers filled the questioner form by simple random sampling. For data processing, it used the IBM SPSS AMOS 22 application that using Structural Equation Model. SEM is a statistical modeling technique that combines factor analysis and regression or path analysis statistical analysis tools, combining factor analysis and regression (Boateng, 2020).

The output targets got firstly, data processing results of each variable with the measurement model test. Data processing results by testing all variables influence quality work of life with full structure model test and getting the final model of the effect of quality work of life on the desire to leave Maranatha Christian University's Job. I was getting the formulation of statistical data from the final model of quality work of life on the perception of leaving a job of Maranatha Christian University lecturers.

\section{RESULT AND DISCUSSION}

\subsection{Result of the construct testing}

Construction testing here is a constructive test of model perceptions of leaving the job using Amos software. There are six constructs of the model tested individually by AMOS 22. After the trimming process, only four constructs are available. In the following is the explanation.

1. Job characteristics

In the calculation process with Amos software, two manifests do not meet the requirements X10 = Responsibility and X11 = Expertise, so it omits the two manifests in the trimming.

2. Wages and numeration

We can achieve validity of salary and allowance construct comprising X21 to X26 all so that there is no need to do trimming process.

3. Job satisfaction

There is a trimming process in the construction of job satisfaction where the removal of manifest X31 "Working conditions" to be axiomatic does not affect Maranatha Christian University lecturers' satisfaction.

4. Perception of leaving the job

The trimming process occurs in manifest X33 = Work in the same industry and X3 = Work in different fields because we found it did not fill the validity requirement, so we eliminated it.

\subsection{The entire structural model testing}

From the calculation of each construct variable, we will continue with the full structural model, where the results are as stated in Table 2 below. 
Table 2. Estimated calculation of trimming model effect of quality work of life on the perception of leaving the job

\begin{tabular}{lcccc}
\multicolumn{1}{c}{ Construct } & Estimate & S.E. & C.R. & P \\
\hline Job_Satisfaction <--- Work_Ethic & 0,101 & 0,117 & 0,856 & 0,392 \\
Job_Satisfaction <---Supervision_Style & 0,701 & 0,132 & 5,330 & $* * *$ \\
Job_Satisfaction <--- Job_Characteristic & $-0,142$ & 0,313 & $-0,452$ & 0,651 \\
Job_Satisfaction <--- Wages Numeration & 0,791 & 0,235 & 3,375 & $* * *$ \\
Job_Satisfaction <--- Job_Satisfaction & $-0,133$ & 0,103 & $-1,283$ & 0,200 \\
\hline
\end{tabular}

Source: Result of data processing by AMOS 22 (2020)

The trimming process of the full structure model eliminated invalid relationships. Then as the final results, two relationships meet the validity requirements. Firstly the relationship between supervision style and job satisfaction.

\subsection{The hypothesis results}

Regarding the final trimming model results, the effect of quality work of life on perceptions of leaving the job, we will see the hypothesis's compliance. Hypothesis I, II, and V were not proven to impact the lecturers' perception to leave the job. Hypothesis III that there is a relationship between the constructs of wages and numeration and job satisfaction. Hypothesis IV that there is a relationship between supervision style construct and job satisfaction.

\subsection{The final model of the influence of quality work of life}

Based on that result, it can capture the figure of the last model of the influence of quality work of life to perception of leaving the job as in this following.

\section{Final model of The influence of quality work of life to perception of leaving the job}

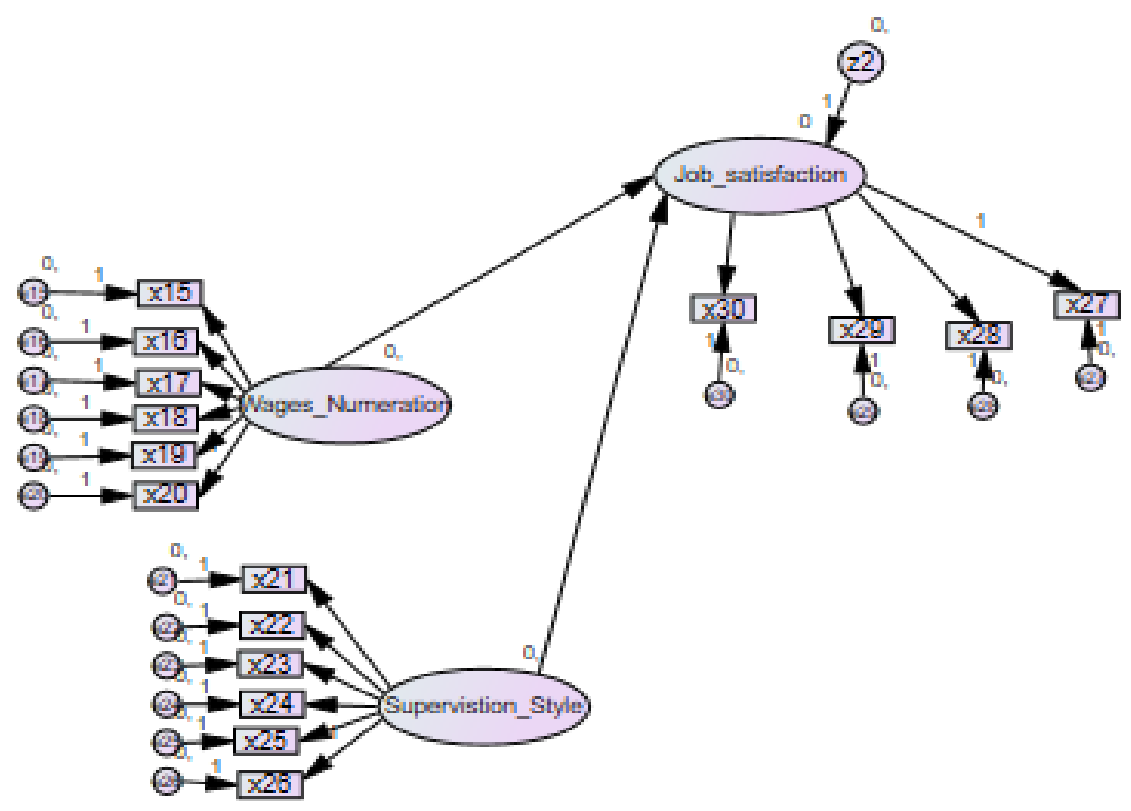

Figure 2. The final model of the influence of quality work of life to the perception of leaving the job Source: Amos figure (2020)

When expressed in a regression equation, the construct is as follows (Santosa, 2014):

$\mathrm{JS}=\beta 1 \mathrm{SS}+\mathrm{z} 2$

$\mathrm{JS}=\beta 1 \mathrm{WN}+\mathrm{z} 2$ 
Described in the construct of an equation are as follows:

$\mathrm{JS}=0,68 \mathrm{SS}+0,09$

$\mathrm{JS}=0,81 \mathrm{WN}+0,09$

$\mathrm{JS}=\mathrm{Job}$ Satisfaction, $\mathrm{SS}=$ Supervision Style, $\mathrm{WN}=$ Wages Numeration

Finally, we drew the final model of the influence of quality work of life. We found a positive impact on supervision style to job satisfaction, is equal with what Qureshi et al. (2019) found in their research. Moreover, understanding the influence of leadership style on job satisfaction will support the organization on their commitment to giving the best services (Babalola, 2016). The past reserch showed that wages have a significant and positive association with employees' job satisfaction (Malik et al., 2012). However, each individual has different criteria for measuring job satisfaction factors, such as payment, working hours, schedule, benefits, level of stress, and flexibility (Abuhashesh et al., 2019). Indicated job satisfaction plays a significant role in achieving a committed workforce, so an organization needs to develop its employees' job satisfaction (Cañizares \& García, 2012). Moreover, job satisfaction has shown a very significant impact on the level of organizational commitment as staying on the job (Saxena et al., 2019). As Grund \& Rubin (2017) stated, wages numeration significantly influences job satisfaction. The same result was found in data processing on the full structure model with AMOS 22 as the second relationship between wages numeration on job satisfaction.

\section{CONCLUSION}

Full structure model test results indicate that the manifest and construct's significance as an above process can conclude as follows. For lecturers at Maranatha Christian University, the quality work of life does not significantly affect the lecturers' desire to withdraw from work. However, the style of supervision and wage numeration positively influences job satisfaction, although it cannot strengthen the lecturers' leaving the job.

The supervisory style construct has six manifests, namely X21 $=$ Support, $\mathrm{X} 22=$ Sharing information, X23 = Fair, X24 = Motivation, X25 = Planning, and X26 = Positive effort. They have a clear influence on job satisfaction. It means needed a further evaluation from decision-makers regarding encouraging, motivating, achieving justice, sharing information, developing plans, and maintaining positive efforts for lecturers.

There is a positive relationship between wages numeration's constructs towards job satisfaction. As we know it, the six constructs of wages numeration are X15 = Happy with salary, X16 $=$ Expertise and effort, $\mathrm{X} 17=$ Workload, X18 $=$ Friends, X19 $=$ System, and X20 = Compensation and rewards. We can determine that being satisfied with the salary, the salary's suitability with the expertise, the workload, the equal salary with peers, and the reward system influence how lecturers supervise their co-workers.

Because of wages numeration's positive effect for Maranatha Christian University's lecture to feel satisfied on their job, the other impact of disappointment on this factor would increase the perception of leaving the job. A review of lecturers' job satisfaction needs to access, because the change of officials who operate the supervisory function is constantly shifting and the factors for regularly granting salaries and allowance. The goal is to enhance the lecturers' satisfaction, so the hope of reducing the Maranatha Christian University lecturers' turnover is achievable.

\section{REFERENCES}

Abuhashesh, M., Al-Dmour, R., \& Masa'deh, R. (2019). Factors that affect employees job satisfaction and performance to increase customers' satisfactions. Journal of Human Resources Management Research, 2019(April), 1-23. https://doi.org/10.5171/2019.354277

Almarsh, S. O (2015). A measurement scale for evaluating the quality of work-life: Conceptualization and empirical validation. Trends in Applied Sciences Research, 10(3), 143-156. https://doi.org/10.3923/tasr.2015.143.156

Alzalabani, A. H. (2017). A study on perception of the quality of work-life and job satisfaction: Evidence from Saudi Arabia. Arabian Journal of Business Management Review, 7(2), 1-9. https://doi.org/10.4172/2223-5833.1000294 
Amani, J. (2016). Relationship between job satisfaction and turnover intention among lecturers in Tanzanian Public Universities. Annals of Modern Education, 8(1), 1-15. https://www.researchgate.net/publication/341479849_Relationship_between_Job_Satisfaction_and_T urnover_Intention_Among_Lecturers_in_Tanzanian_Public_Universities

Babalola, S. S. (2016). The effect of leadership style, job satisfaction, and employee-supervisor relationship on job performance and organizational commitment. Journal of Applied Business Research, 32(3), 935946. https://doi.org/10.19030/jabr.v32i3.9667

Boateng, S. L. (2020) Structural equation modeling (SEM): Made easy for business and social science research using SPSS and AMOS. Kindle Direct Publishing

Burrell, S. (2014). IT staff turnover intentions, job modification, and the effects of work recognition at large public higher education institutions. Electronic Theses \& Dissertations. https://digitalcommons.georgiasouthern.edu/etd/1099

Cañizares, S. M. S., \& García, F. J. F. (2012). Organizational commitment and job satisfaction: An empirical analysis of their relationship in private teachers. Human resource management in the digital economy: Creating synergy between competency models and information, edited by Susana de Juana-Espinosa, et al., IGI Global, January, 138-161. https://doi.org/10.4018/978-1-61350-207-5.ch008

Farid, H., Izadi, Z., Ismail, I. A., \& Alipour, F. (2015). Relationship between quality of work-life and organizational commitment among lecturers in a Malaysian public research university. Social Science Journal, 52(1), 54-61. https://doi.org/10.1016/j.soscij.2014.09.003

Grund, C., \& Rubin, M. (2017). Social comparisons of wage increases and job satisfaction. Applied Economics, 49(14), 1345-1350. https://doi.org/10.1080/00036846.2016.1217311

Korunka, C., \& Hoonakker, P. L. T. (2014). The Impact of ICT on quality of working life. Dordrecht: Publisher Springer. https://doi.org/10.1007/978-94-017-8854-0

Malik, M. E., Danish, R. Q., \& Munir, Y. (2012). The impact of pay and promotion on job satisfaction: Evidence from higher education institutes of Pakistan. American Journal of Economics, 2(4), 6-9. https://doi.org/10.5923/j.economics.20120001.02

Mesimo-Ogunsanya, E. A. (2017). Organizational support and employees' work-life quality. Walden Dissertations and Doctoral Studies. https://scholarworks.waldenu.edu/dissanddoc

Mirkamali, S. M., \& Thani, F. N. (2011). A study on the quality of work-life (QWL) among faculty members of the University of Tehran (U.T.) and Sharif University of Technology (SUT). Procedia-Social and Behavioral Sciences, 29, 179-187. https://doi.org/10.1016/j.sbspro.2011.11.223

Panigrahi, S. K., \& Al-Nashash, H. M. (2019). Quality work ethics and job satisfaction: An empirical analysis. Quality - Access to Success, 20(168), 41-47. https://doi.org/10.2139/ssrn.3515072

Qureshi, M. A., Syed, K. B. S., Brohi, N. A., Soomro, A. B., \& Mushtaque, T. (2019). Impact of job clarity on nurses' job satisfaction: A moderating role of fairness perception. International Business Research, 12(4), 1-11. https://doi.org/10.5539/ibr.v12n4p187

Rizwan, M. (2014). Determinants of employees' intention to leave. International Journal of Human Resource Studies, 4(3), 1-18. doi:10.5296/ijhrs.v4i3.5871

Santosa, S. (2014). Structural equation modeling (SEM). Elex Media Komputindo

Saxena, S., Tomar, K., \& Tomar, S. (2019). Impact of job satisfaction on organizational citizenship behavior. SSRN Electronic Journal, February. https://doi.org/10.2139/ssrn.3323753

Sugianto, Hermanto, B., Muhyi, H. A., \& Purnomo, M. (2018). The effect of job characteristics on job satisfaction and its impact on employee performance. Advances in Social Sciences Research Journal, 5(9), 95-101. doi:10.14738/assri.59.5172

Tangdigling, D. E., Nursyamsi, I., \& Yusuf, R. M. (2019). Pengaruh kepemimpinan situasional dan etos kerja terhadap kinerja pegawai melalui iklim organisasi sebagai variabel intervening pada Politeknik Pembangunan Pertanian Gowa. Hasanuddin Journal of Business Strategy, 1(4), 43-50. https://feb.unhas.ac.id/jurnal/index.php/HJBS/article/view/285/187

Vermandere, C. (2013). Impact of salary on job satisfaction. European Foundation for the Improvement of Living and Working Conditions. https://www.eurofound.europa.eu/publications/article/2013/impactof-salary-on-job-satisfaction

Zamanan, M. S., Alkhaldi, M. H., Almajroub, A. S., Alajmi, A. D. S., Alshammari, J. M., \& Aburumman, O. J. (2020). The influence of HRM practices and employees' satisfaction on intention to leave. Management Science Letters, 10(8), 1887-1894. https://doi.org/10.5267/j.msl.2019.12.030 